УДК 811.161.2’373

\title{
ОКАЗІОНАЛЬНІ ФРАЗЕОЛОГІЗМИ В ТЕКСТАХ СУЧАСНОЇ УКРАЇНСЫКОЇ ПРОЗИ
}

Бузько С. А. Оказіональні фразеологізми в текстах сучасної української прози.

У статті описано індивідуально-авторські (оказіональні) трансформації одиниць фразеологічного мовного рівня, що використовуються в текстах сучасної української прози, зокрема у творах М. Матіос, Ю. Андруховича та ін.

Ключові слова: оказіональна трансформація, узуальна (оказіональна) фразеологічна одиниця, стилістичний ефект.

() С. А. Бузько, 2014.

$-152-$ 
Бузько С. А. Окказиональные фразеологизмы в текстах современной украинской прозы.

В статье описаны индивидуально-авторские (окказиональные) трансформации единиц фразеологического языкового уровня, которые используются в текстах современной украинской прозы, в частности в произведениях М. Матиос, Ю. Андруховича и др.

Ключевые слова: окказиональная трансформация, узуальная (окказиональная) фразеологическая единица, стилистический эффект.

Buzko S.A. Occasional phraseological units in modern Ukrainian prose.

The individual-author's (occasional) transformations of units of phraseological linguistic level used in texts of modern Ukrainian prose, particularly in M.Matios's, Y.Andruhovych's and others' compositions, are described in the article.

Key words: occasional transformation, usage (occasional) phraseological unit, stylistic effect.

Оказіональні фразеологізми вивчаються в межах загальної проблеми різноманітних виявів оказіональності в мовленні, зокрема в лексиці та фразеології. У «Словнику лінгвістичних термінів» О. Ахманової подається таке визначення оказіонального явища: «не узуальний, такий, що не відповідає загальноприйнятому вживанню, характеризується індивідуальним смаком, зумовлений специфічним контекстом уживання» [1, с. 147]. Таке широке розуміння оказіональності дає підстави вживати цей термін стосовно будь-якого факту індивідуально-авторської творчості. На лексико-фразеологічному мовному рівні, крім оказіональних лексем, виникають незвичні індивідуально-авторські (оказіональні) фразеологізми, що роблять художній текст більш «свіжим» та виразним.

Загальновідомо, що фразеологізми, як і інші лексичні шари, відіграють важливу роль у побудові художнього тексту. «Слід зазначити, що образність мови, іiі стилістичні можливості доповнюються і збагачуються завдяки використанню стилістичних прийомів контекстуального перетворення фразеологічних зворотів» $[3$, с. 56]. За ознакою відтворюваності в мовленні та усталеності компонентного складу відносимо до фразеологізмів також прислів'я, приказки, афористичні вислови. Оскільки трансформація як стилістичний засіб реалізується через цілеспрямовану модифікацію форми вираження та оновлення семантики узуальних фразеологічних одиниць, вона «неодмінно передбачає стилістичну мету, бо породжена прагненням адресанта органічно поєднати, злити воєдино з контекстом загальновідомий вираз, уточнити чи деталізувати значення фраземи у зв'язку з конкретною мовленнєвою ситуацією» [8, с. 178]. Спробуємо 
проаналізувати стилістичні ефекти, що виникають у результаті оказіональної трансформації узуальних фразеологічних одиниць. Під оказіональною трансформацією маємо на увазі зміни в структурі звичних, загальномовних фразеологізмів, що спричиняють відповідні зміни в семантиці (оновлення, конкретизація змісту, нашарування додаткових відтінків значень тощо) і таким чином створюють певний стилістичний ефект. Матеріалом для написання статті послугували художні прозові тексти сучасних авторів, зокрема Ю. Андруховича, Ю. Іздрика, О. Іранця, І. Карпи, М. Матіос та С. Поваляєвої.

У ряді прикладів трансформація відбувається завдяки включенню до структури узуальної фразеологічної одиниці додаткового компонента чи компонентів, які оновлюють, індивідуалізують іiі семантику: Теж міцний горішок. Явно не волоський (9, с. 83). За допомогою парцеляції до складу фразеологізму введено атрибутивний компонент явно не волоський, який посилює значення вихідної одиниці («людина зі складним характером») і надає оповіді іронічного забарвлення. Не менш іронічно звучить така характеристика: телепилип з конопель Пліховшек (9, с. 38). Додаванням однієї морфеми авторка (М. Матіос) уточнює, конкретизує значення фразеологізму, пов'язуючи його 3 конкретною мовленнєвою ситуацією. Аналогічний, але більш складний спосіб трансформації спостерігаємо в наступних прикладах: Безперечно, щзо тепер усі вони страждають і караються, але не каються, а навпаки жсадають пива і видовищ (2, с. 133); Рукописи не горять, а гниютьтаки порядно (7, с. 209); І не обминути ичієї любові ні пішим ходом, ні конем не об'їхати, ні «Боӥнгом» не облетіми. Бо це - любов (9, с. 68). Особливий стилістичний ефект створюють у подібних випадках лексеми на позначення реалій сучасного життя (як-от, слова пиво, «Боїнг» у наведених прикладах). Це $є$ свідченням того, що на сучасному етапі розвитку мови «за наявними у фразеологічній системі зразками активно продукуються фраземи, матеріальна форма вираження яких засвідчує «смаки епохи», відповідає потребам часу» [8, с. 181].

В окремих ситуаціях трансформація здійснюється за рахунок заміни окремих компонентів усталеного виразу індивідуально-авторськими: не так тії вороги, як... Правильно, як любії друзі (9, с. 24). Замість очікуваного шевченківського «добрії люди» читач наштовхується на відвертий саркастичний натяк, суть якого неважко зрозуміти тим, хто хоч би поверхово цікавиться суспільно-політичним життям країни. Впадають в око такі трансформовані афоризми, у яких видозміна компонентного ๑) С. А. Бузько, 2014. 
складу особливо непередбачувана. Згадаймо відомого гоголівського героя і його не менш відомий вислів, який став крилатим і який так оригінально обігрує М.Матіос: Я тебе, синку, породив... Але уб'ю не тебе, а твою пасію (9, с. 83). Своєрідна, несподівана трансформація не лише оновлює семантику того чи іншого відомого виразу, ніби пристосовуючи його значення до змісту твору, але й створює ефект комічного, наприклад: Чим би дитя не тішилося, аби не вішалося (10, с. 37); $\boldsymbol{A}$ діми мойх друзів - це мої діми (2, с. 139). Такі оказіональні новоутворення деавтоматизують мовні стереотипи і стимулюють співтворчість автора 3 читачем [12, с. 14]. Трансформовані оказіональні фраземи викликають у пам'яті читача первісні фразеологічні одиниці; реципієнт порівнює зміст первісного фразеологізму та його оновлене значення в певному текстовому уривку. Це породжує стилістичний ефект, адже нова форма та розширена семантика трансформованих фразеологізмів дають можливість якоюсь мірою загострити сприйняття тексту, збагативши читацьку уяву.

Інколи письменники трансформують усі або майже всі компоненти усталеного словесного комплексу і таким чином мовби натякають на узуальний фразеологізм («прийом фразеологічної алюзії) [3, с. 59]). Наприклад: винахідник нової формули потрійного вступання в одне $\boldsymbol{i}$ те жс лайно; доктор без дисертації (9, с. 37; 39). Очевидно, у першому прикладі натяк на загальновідоме твердження про неможливість дворазового входження в одну й ту саму ріку; у другому виникає асоціація 3 російським фразеологізмом сапожник без сапог (укр. На те він $і$ кравець, щзоб подертий жупан носити). В обох ситуаціях автор розширює семантичне поле узуальних фразем, наближаючи їх до тих мовленнєвих ситуацій, які спричинили появу оказіональних фразеологізмів; цей прийом підкреслює іронічносаркастичний тон звучання оповіді. Зазначений прийом фразеологічної алюзії використовується й у таких уривках: намірів у мене жодних (ними жс вистелена дорога відомо куди) (4, с. 151); використовуючи ситуацію рака на безриблї (5, с. 74).

Загалом контраст між узуальним наповненням фразеологізмів та їх оказіональною реалізацією посилює експресивно-стилістичний ефект подібних утворень. Увага читача привертається вже тим, що відомі вирази відтворюються незвично, оригінально, у видозміненому вигляді. На думку В. Чабаненка, лінгвостилістичне значення трансформованих фразеологізмів, зокрема прислів'їв, приказок, крилатих висловів та 
інших сталих зворотів, «полягає не тільки в тому, що вони роблять художній або публіцистичний текст більш виразним, а й у тому, що вони збагачують, відсвіжують палітру української загальнонародної мови в цілому» $[11$, с. 288].

Важливо також відзначити, що оказіональні фразеологічні утворення посилюють інтертекстуальні зв'язки постмодерних текстів із текстами інших культурних епох або 3 народно-розмовною фразеологією. За спостереженнями О. Калити, у сучасних художніх текстах простежується тенденція до збільшення кількості трансформованих цитат. «Це явище можна пояснити тим, - зауважує дослідниця, - що трансформована цитата має більший потенціал для вираження авторської іронічної позиції, бо трансформація може збільшувати експресивність цитати та зміщувати смислові акценти» [6, с. 12].

Отже, в одному разі трансформація загальномовних фразеологізмів відбувається завдяки залученню до структури узуальної фразеологічної одиниці додаткового компонента чи компонентів, які оновлюють, індивідуалізують іiі семантику, в іншому - за рахунок заміни окремих компонентів усталеного виразу індивідуально-авторськими. Інколи письменники трансформують усі або майже всі компоненти усталеного словесного комплексу, ніби натякаючи на узуальний фразеологізм («прийом фразеологічної алюзії»). Подібні контрасти між узуальним наповненням фразеологізмів та їх оказіональною реалізацією посилюють експресивно-стилістичний ефект подібних утворень, підкреслюють комізм зображуваних ситуацій або посилюють ігровий характер розповіді, роблячи таким чином художнє мовлення оригінальним, емоційним і непередбачуваним.

\section{Література}

1. Ахманова О. С. Словарь лингвистических терминов / О. С. Ахманова. - М. : Советская энциклопедия, 1966. - 606 с.

2. Андрухович Ю. Рекреації : [романи] / Юрій Андрухович. - К. : Вид-во «Час», 1997. - $287 \mathrm{c}$.

3. Григораш А. М. Трансформація складу фразеологізмів у газетних текстах / А. М. Григораш // Система і структура східнослов'янських мов : зб. наук. праць. - К. : Знання, 1997. - С. 56-61.

4. Іздрик Ю. Подвійний Леон / Юрій Іздрик. - Івано-Франківськ : Лілея-НВ, 2000. $-204 \mathrm{c}$.

5. Ірванець О. Рівне/Ровно (стіна) : [нібито роман] / Олександр Ірванець. - Львів : Кальварія, 2002. - 189 с.

6. Калита О. М. Мовні засоби вираження іронії в сучасній українській малій прозі : автореф. дис. ... канд. філол. наук / О. М. Калита. - К., 2006. - 20 с.

(ㄷ. С. А. Бузько, 2014.

$-156-$ 
7. Карпа I. 50 хвилин трави : [новели] / Ірена Карпа. - Львів : Кальварія, 2006. - 238 с.

8. Колоїз Ж. В. Українська оказіональна деривація : [монографія] / Ж. В. Колоїз. К. : Акцент, 2007. - 311 с. 101.

9. Матіос М. Містер і місіс Ю-Ко в країні укрів. Mr. \& Ms. U-Ko in country UA / Марія Матіос. - Львів : ЛА «Піраміда», 2006. - 136 с.

10. Поваляєва С. Ексгумація міста : [новели] / Світлана Поваляєва. - Львів : Кальварія, 2006. - 160 с.

11. Чабаненко В. А. Стилістика експресивних засобів української мови / В. А. Чабаненко. - Запоріжжя, 2002. - 351 с.

12. Юрченко Т.Г. Оказіоналізми у творчості Павла Загребельного : структурносемантичний і стилістичний аспекти : автореф. дис. ... канд. філол. наук / Т. Г. Юрченко. K., 2003. - 18 c.

Стаття надійшла до редакиї 03.11.2014 p. 